\title{
Air Pollution of Particulate Matter and its Effect on Red Blood Cell Membranes
}

\author{
Orel $\mathbf{M}^{1}$, Berglez $\mathrm{K}^{1}$, Skube $\mathrm{U}^{2}$, Bele $\mathbf{M}^{3}$, Božič $\mathrm{D}^{1,4}$ Kroflič $\mathrm{A}^{2, *}$, Jeran $\mathbf{M}^{1,4, *}$ \\ 1. University of Ljubljana, Faculty of Health Sciences, Laboratory Clinical Biophysics, Ljubljana, Slovenia \\ 2. National Institute of Chemistry, Department of Analytical Chemistry, Ljubljana, Slovenia \\ 3. National Institute of Chemistry, Department of Materials Chemistry, Ljubljana, Slovenia \\ 4. University of Ljubljana, Faculty of Electrical Engineering, Laboratory of Physics, Ljubljana, Slovenia \\ * Correspondence: Marko Jeran; marko.jeran@fe.uni-lj.si \& Ana Kroflič; ana.kroflic@ki.si
}

Citation: Orel M, Berglez K, Skube U, Bele M, Božič D, Kroflič A, Jeran M. Air Pollution of Particulate Matter (PM) and its Effect on Red Blood Cell Membranes. Proceedings of Socratic Lectures. 2021; 6: 77-86. https://doi.org/10.55295/PSL.2021.D. 011

Publisher's Note: UL ZF stays neutral with regard to jurisdictional claims in published maps and institutional affiliations.

Copyright: $₫ 2021$ by the authors. Submitted for possible open access publication under the terms and conditions of the Creative Commons Attribution (CC BY) license (https://creativecommons.org/license s/by/4.0/).

\begin{abstract}
Particulate matter (PM) is classified as one of the most dangerous air pollutants which cause numerous adverse health effects. Prolonged exposure to high PM concentrations can lead to serious health complications and severe chronic conditions. Our research work is focused on the concentration of PM particles in ambient air. We studied how the concentration changes with different seasons (summer and autumn). The results of our experimental work show that the concentration of PM in the air increased during the colder period of the year. In autumn, the average daily mass concentration was determined at $0.85 \mu \mathrm{g} / \mathrm{m}^{3}$, which means it was over the daily limit set by the WHO. These results indicate that the level of air pollution has a detrimental impact on human health in Ljubljana, the capital city of Slovenia. Due to strong impacts of PM particles on our body, we further studied the impact of PM10 particles on human blood erythrocytes, with the aim of interdisciplinary synthesis of knowledge from the scientific fields like environmental protection and medicine. The results of in vitro studies show that a prolonged exposure to increasing concentration of $\mathrm{PM}_{10}$ particles causes a decrease in erythrocyte population. We also observed changes in membrane shapes when erythrocytes were exposed to PM particles for a longer time. We also observed the transition from echinocyte to stomatocyte cell shape with help of a scanning electron microscope (SEM). The results of this research can be used as a basis for more extensive research on the systemic impact of inhaled PM particles on the human body.
\end{abstract}

Keywords: PM particles, air pollution, cell response, erythrocytes, erythrocyte membranes, medicine 


\section{Introduction}

\subsection{Particulate matter (PM)}

Particulate matter or PM is a mixture of solid particles and liquid droplets that can be found floating in the Earth's atmosphere. PM particles are one of the main air pollutants and are divided into different groups according to their size. The most common and the most dangerous are particles named $\mathrm{PM}_{2.5}$ and $\mathrm{PM}_{10}$. The numbers next to the abbreviation indicate the largest aerodynamic diameter of the particles in a particular group (Lesjak, 2016). PM groups are composed mainly of inorganic ions, but they can also contain organic and inorganic carbon and traces of toxic metals (Siwek et al., 2016). Carbon represents a high percentage of atmospheric particles, especially in urban areas. It occurs in various forms, which can be broadly divided into three groups: organic carbon, elemental or black carbon and carbonates $\left(\mathrm{CO}_{3}{ }^{2-}\right)$. Carbon in all his forms plays and important role in terms of its impact on health, chemical processes in the atmosphere, visibility, and effects on climate change (Siwek et al., 2016).

\subsection{Main sources of pollution}

PM can originate both from natural and anthropogenic sources. Natural sources of air pollution with PM particles include desert dust, volcanic eruptions, forest fires and marine aerosols, while anthropogenic sources include combustion emissions of fuels in thermal power stations, industrial emissions, emissions from heating and traffic (Bilban, 2014). The largest anthropogenic sources of PM particles are household combustion and emissions of the service sector. The woody biomass is the largest source of organic particles in atmospheric aerosol, which makes the use of small combustion facilities particularly problematic. In addition to heating, traffic is also one of the biggest producers of particulate emissions in urban areas. The situation gets even more severe during the winter time, when the phenomenon of temperature inversion restricts the passage of polluted air into the higher layers of the atmosphere and causes the highest level of air pollution (Agencija Republike Slovenije za okolje, 2019).

\subsection{Effects of PM particles on human health}

Ambient air pollution is the major cause of premature death in Europe. Moreover, PM pollution importantly increases the risk for the development of cardiovascular and respiratory diseases, and lung cancer. Exposure to polluted air can cause reduced lung function, respiratory infections or asthma in children and adults, while the exposure of pregnant women to particulate emissions can affect fertility, the course of pregnancy, and the development of foetus itself. The results of various studies have shown that polluted air can affect the progression of type 2 diabetes, it can as well cause obesity, premature aging, and onset of Alzheimer's disease and dementia (European Environment Agency, 2019).

As $\mathrm{PM}_{2.5}$ particles are much smaller in diameter than $\mathrm{PM}_{10}$ particles, when inhaled, it is easier for them to penetrate deep into the body all the way to pulmonary alveoli. After absorption into the bloodstream, they cause narrowing of the blood vessels and formation of cloths, which can lead to heart failure or hearth attack. Some of the studies have shown that $\mathrm{PM}_{2.5}$ particles reduce cognitive abilities due to faster brain aging and disruption of communication between different parts of the brain (European Environment Agency, 2019).

\subsection{Interaction with biological material}

The effects of PM particles on human health depend on the size and shape of the particles, as well as their chemical composition. The most common way of entering the body is through the airways of respiratory tract, from where the smallest particles can reach just about any part of the lungs. After they enter the lungs and interact with lung 
cells, the metal part of the particles oxidizes, which causes damage to the DNA structures and increases the risk of developing cancer and respiratory diseases, like bronchitis (European Environment Agency, 2019). Studies have shown that exposure to nanoparticles raises the risk of pulmonary inflammation, which can be later transmitted to other organs (liver, heart, spleen, and brain) through the circulatory system (Bilban, 2019). Some pathophysiological changes associated with cardiovascular diseases, like changes in heart rate, high blood pressure, and arrhythmia, were also observed. It was proven that if we increase the concentration of $250 \mathrm{~nm}$ particles for $10 \mu \mathrm{g} / \mathrm{m}^{3}$, there will be an $8-18 \%$ increase in mortality from malignant cardiac rhythm disturbances or cardiac arrest (Bilban, 2019).

\subsection{Cell membrane}

The cell membrane, also called the plasma membrane, is one of the main parts of any cell. Its main task is to protect the cell and regulate the transport of materials entering and exiting the cell. It consists of phospholipid bilayer which provides elasticity and fluidity of the cell. The amphiphilic character of phospholipid molecules allows membrane lipids to build a stabile bilayer in an aquatic environment (Pečavar Nežmah, 2018). In addition to phospholipids, the membrane also contains lipids, which belong to the group of glycolipids and cholesterols. Glycolipids are located on the outer part of the membrane - to protect the cell, while cholesterols are important primarily because they increase impermeability of the membrane to certain substances, reduce the fluidity of the outer membrane when temperature is high and prevent the membrane from freezing or decreasing its fluidity when temperature is low (Pajnič, 2019). Apart from lipids, there are also membrane proteins which are an important building blocks of every cell membrane. The proteins bind with sugar to form glycoproteins, which are responsible for maintaining or changing the shape and structure of a cell, they impact intercellular communication and active/passive transport. They also act like receptors for hormones and other molecules (Pajnič, 2019).

\subsection{Blood and its components}

Blood is a fluid that is constantly circulating through our body and delivers essential substances like oxygen and nutrients to body's cells. It is made up of blood serum (blood plasma and fibrinogen) and blood cells. We know three different forms of blood cells: red blood cells (erythrocytes), white blood cells (leukocytes) and platelets (Hoffman, 2014). Red blood cells carry oxygen to all cells in the body. White blood cells play an important role in defending the body against infections and building resistance with help of antibodies. Platelets and other clotting factors help form clots to stop bleeding (Blood Transfusion Centre of Slovenia, 2021).

\subsection{Red blood cells or erythrocytes}

Red blood cells or erythrocytes are the cells that supply our body with oxygen. The size range of those flattened cells is between 7 and $8 \mu \mathrm{m}$ (American Society of Haematology, 2021). Almost $1 / 3$ of cell's volume represents haemoglobin, a protein which is crucial for the transport of respiratory gases (Orel and Berglez, 2021). Special properties of erythrocyte membranes are reflected in the shape of the whole cell, as erythrocytes do not have an internal cytoskeleton to determine their shape (Lim et al., 2002). Instead, red blood cells have a protein network attached to the inside of the cell membrane, known as the membrane skeleton. Since the skeleton fits everywhere on the phospholipid bilayer, it can be considered as the third membrane layer. Both, phospholipid bilayer and cytoskeleton contribute to membrane elasticity and fluidity that affect deformation of erythrocytes in a bloodstream; the cells easily adapt to changed conditions in the surrounding solution because of the small elastic modulus of their membrane (Lim et al., 2002). Although the diameter of erythrocytes is larger than the diameter of capillaries in the microcirculatory system (Lim et al., 2002), sufficient elasticity and appropriate osmotic 
balance still allow them to pass smoothly through the capillary system. The elastic structure, which allows erythrocytes to optimally adapt to the narrow capillaries, is their key feature. It is important that the erythrocyte cell has enough of its membrane available (this is determined by the osmotic balance); if the membrane is overstretched, it easily ruptures under excessive load, which causes haemolysis (Mohandas et al., 2008).

\section{Methods}

During our research, we used several different research methods. One of them was microscopy - we used both inverted light microscope for observing cells in an aqueous medium and scanning electron microscope (SEM) to observe the surface of solid samples under a beam of electrons. Using this technique, we determined morphology and elemental composition of the studied samples.

For our further research, we used a Particulate Matter (PMx) Sampler, an instrument that allows us to measure mass concentration of PM particles in the air. Using a special filter it collects a particular fraction of particles from the outdoor air, which is later weighed and translated into mass concentration.

We also used a scanning mobility particle sizer (SPMS) spectrometer, a measuring device that measures the size of nanoparticles in the atmosphere in real time.

In the end we used the technique of flow cytometry to measure and analyse properties of individual cells.

\subsection{Particle measurement}

Samples were collected in the premises of the National Institute of Chemistry in Ljubljana and the composition of air was monitored every day from $9^{\text {th }}$ August 2020 to $15^{\text {th }}$ August 2020 and from $22^{\text {nd }}$ November 2020 to $28^{\text {th }}$ November 2020. Each filter was weighed separately before and after the sampling, to accurately determine the difference in mass. By doing this, we determined the mass of collected PM particles during the 24 hours of exposure. Prior to use, the filters were pre-baked at $450{ }^{\circ} \mathrm{C}$ for 4 hours to remove potential organic contaminants.

We weighted the filters in a special air-conditioned room, where the working conditions are constantly monitored $\left(20^{\circ} \mathrm{C}, 45 \% \mathrm{RH}\right)$. We used a scale that was specifically designed to weigh filters. We considered the average filter mass and all potential errors that could occur.

The weighed filters were then placed into a tube, which was inserted into the PM sampler, and we set a sampling programme. Each filter was sampled for 24 hours at an air flow of $2.3 \mathrm{~m}^{3} / \mathrm{h}$. At the end of the sampling procedure, the filters were removed from the sampler and weighed again according to the procedure mentioned above.

In parallel with the PM sampling, we draw the outdoor air into an SMPS Spectrometer, where it was analysed for PM size distribution. In the end, we used SEM to show the binding of PM particles to the filter fibres.

\subsection{Scanning electron microscopy (SEM)}

SEM imaging of ambient PM deposited on a quartz fiber filter was carried out using a Zeiss Supra 35 VP (Carl Zeiss, Oberkochen, Germany) microscope. The operating voltage was at $1 \mathrm{kV}$.

\subsection{Light microscopy}

Blood samples, PM10 particle suspensions, and their mixtures were examined with a Nikon EM CCD inverted light microscope (Eclipse TE2000-S, Tokyo, Japan; coupled with a digital camera system: spot boost, Visitron Systems) at 100× magnification using an immersion oil. $200 \mu \mathrm{L}$ Of diluted blood, particle suspension, or a mixture of PM10 particles with blood were pipetted into experimental perfusion chambers $(26 \mathrm{~mm} \times 43 \mathrm{~mm}$, CoverWell ${ }^{\mathrm{TM}}$, PC4L-0.5, Grace Bio-Labs) for efficient analysis and analytical image acquisition under the microscope. 


\subsection{Effect of PM particles on erythrocyte membranes}

We used a certified reference material, fine dust called ERM-CZ100 PM10-like as a surrogate for ambient PM10 particles. For the treatment, we prepared its 50, 100 and 200 $\mu \mathrm{g} / \mathrm{mL}$ suspensions in sterile conditions (laminar flow) with use of sterile deionized water. For this purpose, we used a stock suspension of $\mathrm{PM}_{10}$ particles with a concentration of $20 \mathrm{mg} / \mathrm{mL}$, which was then added to the working solution of blood or the working buffer solution in appropriately low doses.

To nicely observe the distribution of particles under the microscope, we used samples with approximately $1.0 \times 10^{6}$ cells (events) $/ \mu \mathrm{L}$ in their erythrocyte region. On the basis of previous experience, we pipetted $50.0 \mu \mathrm{L}$ of freshly drawn blood from an adult male into $20.0 \mathrm{~mL}$ of phosphate-citrate buffer, the mixture was homogenised, and the cell concentration was confirmed under the microscope.

Before treatment and after 1, 8, and 24 hours, the prepared samples were quantitatively evaluated by flow cytometry to determine the concentration of erythrocytes. After 1 hour of treatment, control samples were first analysed and detection regions were determined: PM particle population, erythrocyte region, and spherocyte region (Figure 1).
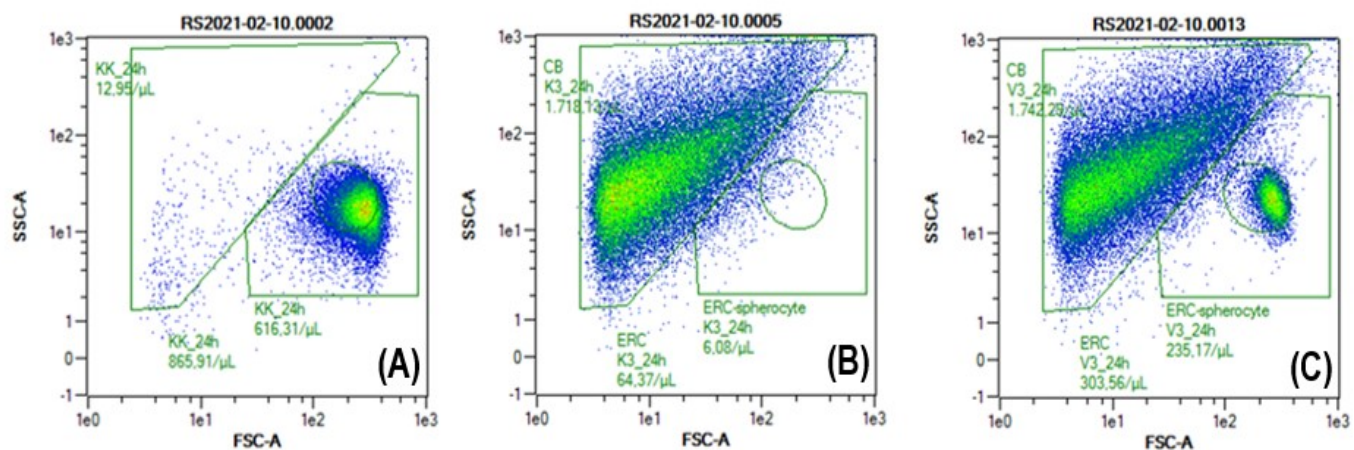

Figure 1. Example of scatter plots after 24 hours: (A) diluted blood, (B) PM10 particles with a concentration of $200 \mu \mathrm{g} / \mathrm{mL}$, and (C) a treated blood sample with a PM10 particles concentration of $200 \mu \mathrm{g} / \mathrm{mL}$. The triangular shape of the region in the upper left corner represents the scattering region of PM10 particles. The region resembling the shape of a rectangle covers the erythrocyte (ERC) region and the region in the central part (circle, ERC-spherocyte) covers the spherocyte forms of the erythrocytes.

\section{Results}

3.1. Results of air sampling with PM particle sampler

Figure 2 shows mass concentrations of PM particles in summer and autumn 2020. The green straight line represents the maximum permissible mass concentration of PM particles in ambient air as defined by WHO, which is not yet considered dangerous to human health. Measurements show that mass concentrations of particles are mostly lower in summer than in autumn. We can attribute this to domestic heating and increased traffic emissions during the transition to the colder part of the year. Still, summer results are expected to be influenced by the local $\mathrm{PM}_{2.5}$ emissions as a consequence of a laboratory cleaning after a fire. 


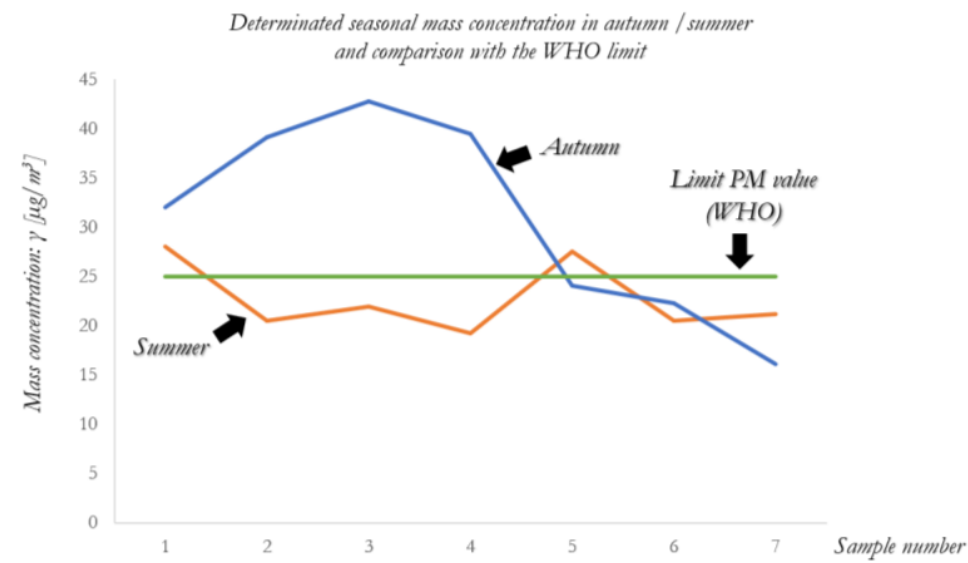

Figure 2. The mass concentration of PM particles in summer and autumn.

Figure 3 shows a SEM image of PM particles collected on a quartz fiber filter in autumn 2020. The fibers in the image represent the filter. A large soot aggregate (white arrow) can be seen in the center of the image. Smaller accumulations of other PM particles (red arrows) can be also seen all around the sample.

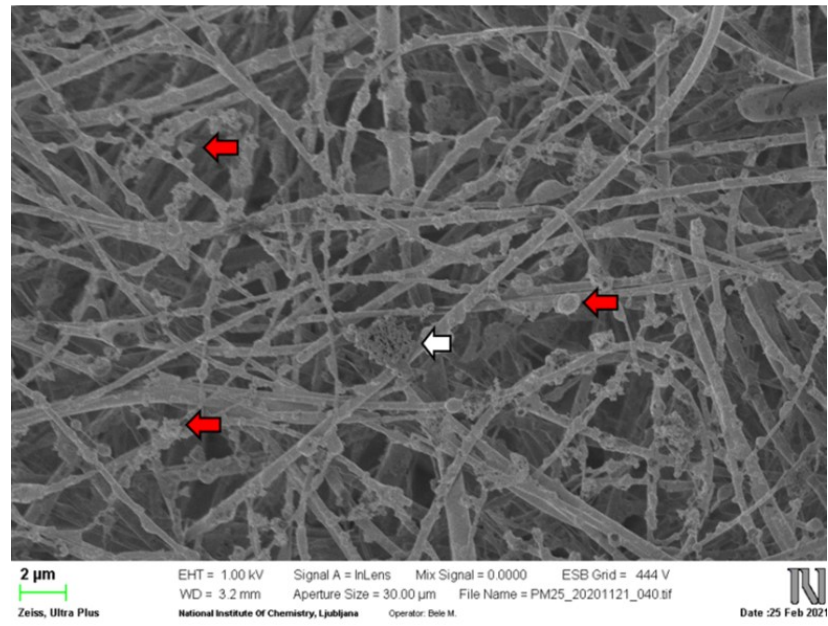

Figure 3. SEM image of a sample collected in autumn 2020.

\subsection{Results of erytrhrocyte population measurements (flow cytometry)}

Figure 4 shows variation over time of the population (cell number) in the negative control (blood) and the samples treated with PM10 particles (c=50, 100 and $200 \mu \mathrm{g} / \mathrm{mL}$ ). After 24-hours exposure and at the highest concentration, the highest impact on of the erythrocyte particles is detected. On the other hand, the lowest impact on erythrocytes is observed at the lowest concentration of PM particles after only one hour of exposure. in general we found out that the number of erythrocytes in the samples decreases with increasing particle concentration and longer exposure to the particles.

The variations in the spherocyte population after 1 and 8 hours of exposure in 50 and $100 \mu \mathrm{g} / \mathrm{mL}$ samples corresponds to the trend of the control sample and cannot be attributed to the treatment. The change in spherocyte population is most pronounced after 24 hours. Variations of the population are mostly proportional to the basic erythrocyte region. 


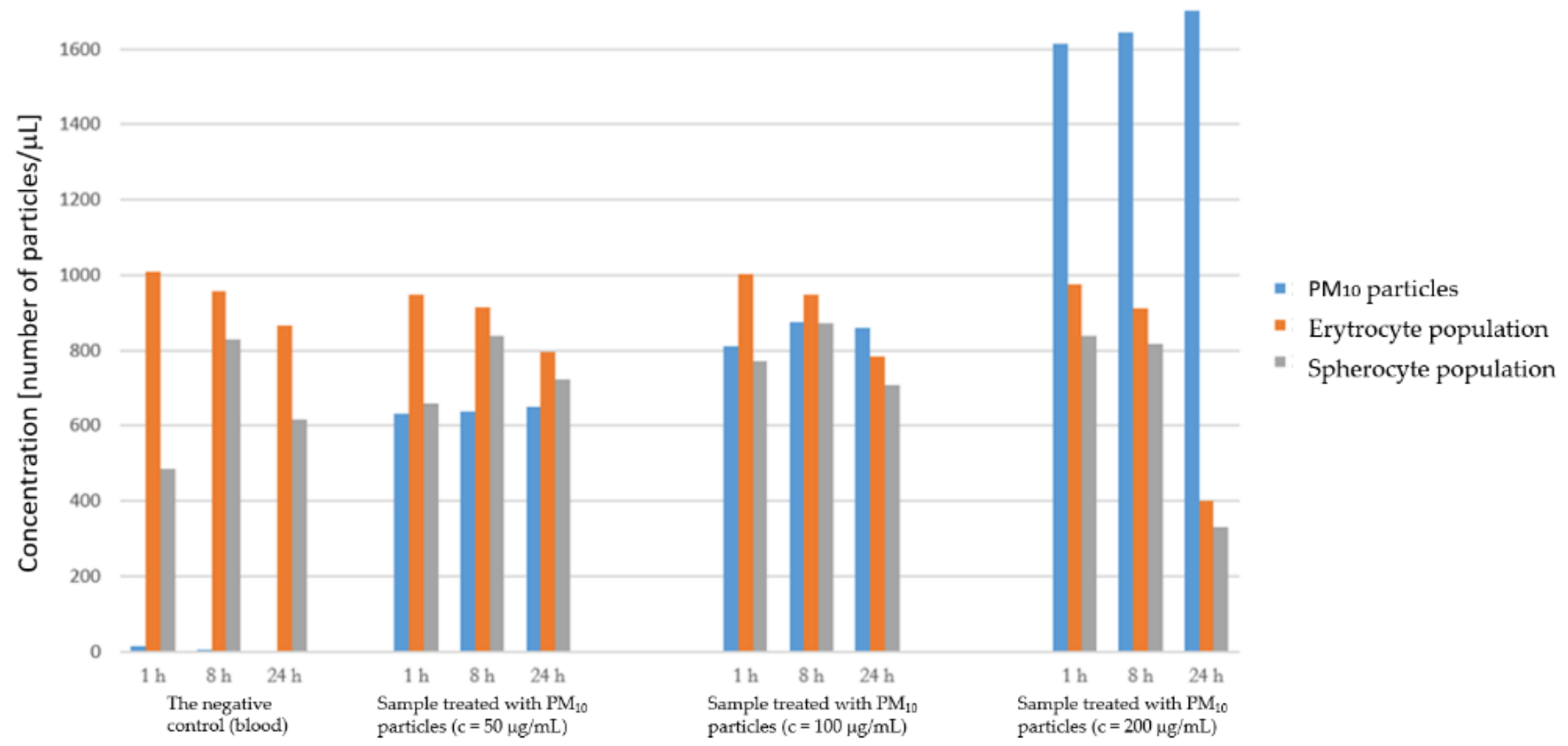

Figure 4. PM particle impact on erytrocyte and spherocyte population in samples (flow cytometry).

\subsection{Results of cell microscopy (inverted light microscope)}
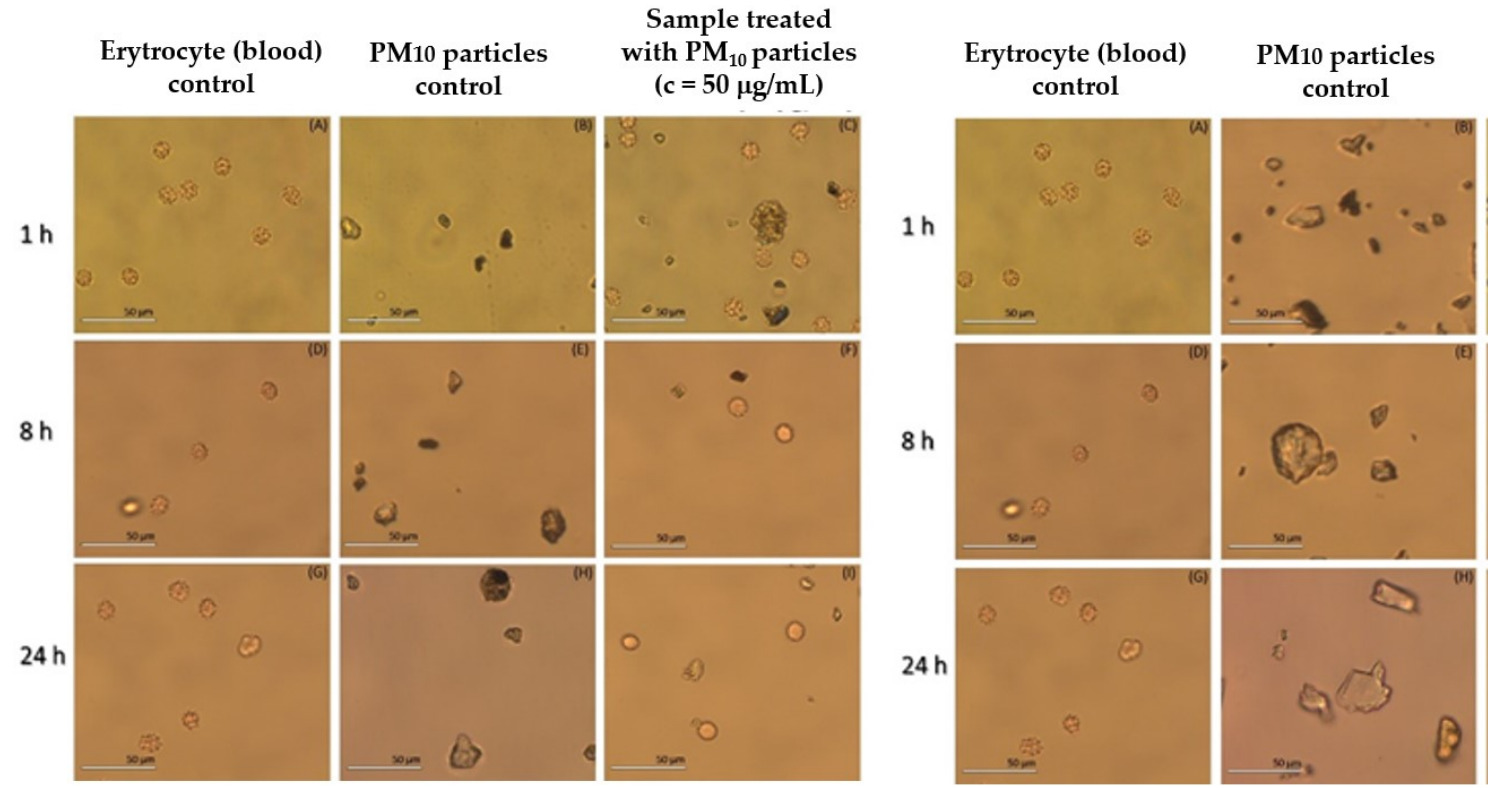

\section{Sample treated with $\mathbf{P M}_{10}$ particles (c $=200 \mu \mathrm{g} / \mathrm{mL}$ )}
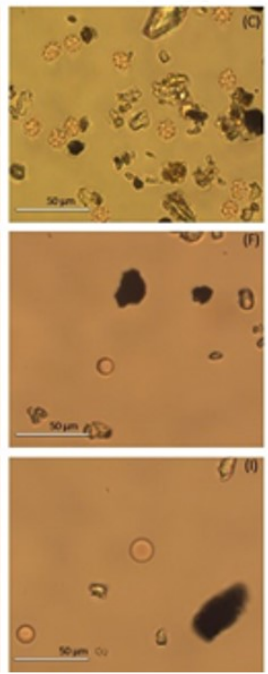

Figure 5. The comparison of the sample with the lowest and the highest concentration of PM particles.

Figure 5 shows the comparison of the samples with the lowest and the highest concentration of PM particles. In both cases, there is only an echinocyte form observed at the beginning of the treatment. However, after several hours of exposure, erythrocytes are transformed from the echinocyte to a stomatocyte form. At higher concentrations of PM particles, this change in shape is observed much earlier. Moreover, it can also be seen that after 24 hours of exposure the membranes in the sample with the highest concentration become very stretched, nearly rupturing. 
After the 24-hour exposure of erythrocytes to PMio particles, at a concentration of 200 $\mu \mathrm{g} / \mathrm{mL}$ we detected extracellular vesicles on the erythrocyte membrane. Extracellular vesicles are membrane-enclosed fragments of a cell membrane that are released by all types of cells into their environment, both in vitro and in vivo. In medicine, vesicles are considered as biomarkers of various diseases.

The presence of PMio particle was probably perceived by erythrocyte cells as a foreign body, which consequently triggered the synthesis of vesicles. The reason for the formation of extracellular vesicles presumably depends on the damage added particles caused on the erythrocyte membrane, causing smaller fragments to be released into the surrounding solution, which resulted in the appearance of vesicles.

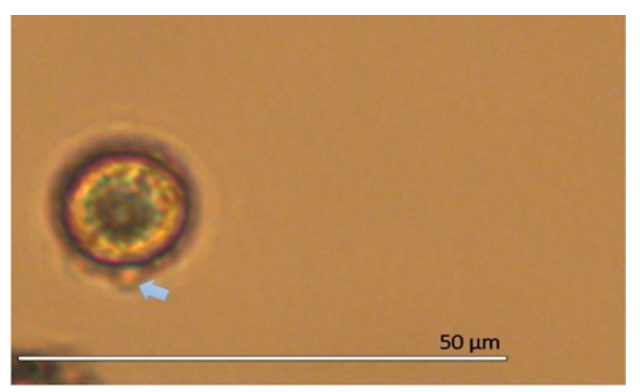

Figure 6. Example of the extracellular vesicle on the erythrocyte membrane.

\section{Discussion}

\subsection{Concentrations of PM particles in the air}

The purpose of our research was to determine when the concentration of PM particles in the atmosphere is the highest and consequently which period of the year is most harmful to human health. Ambient PM concentration was measured at the same monitoring station during different seasons. The average mass concentration of PM particles was $22.71 \mu \mathrm{g} / \mathrm{m}^{3}$ in summer and $30.85 \mu \mathrm{g} / \mathrm{m}^{3}$ in autumn. From the results we gathered, we can conclude that in autumn the concentration of PM particles is higher than that in summer, which is the consequence of household heating and increased traffic emissions in autumn months. One of the largest anthropogenic sources of PM particles in Slovenia are household combustion and emissions of the service sector. The use of small combustion installations, which use wood biomass as a fuel, is particularly problematic and is very common in not so cold autumn days. In addition to heating, traffic and road dust resuspension make a significant contribution to particulate emissions, especially in Ljubljana, where traffic density is the highest in the country. Another reason for higher levels of air pollution is also the phenomenon of temperature inversion, which is especially characteristic for Ljubljana basin. During the summer, the concentration of PM particles in the air was significantly lower, which makes sense since there is no household heating and no temperature inversion in the lowlands. The PM particles in the air originated from traffic emissions, as the PM sampler was placed in the area where traffic is relatively dense. Besides, the obtained results were likely influenced by the already mentioned local origin of $\mathrm{PM}_{2.5}$ particles from cleaning of a laboratory after a fire.

A detailed examination of particle sizes showed that smaller particles were more numerous, while bigger particles represented a bigger mass (data not shown). Smaller particles are more dangerous to human health, since they can penetrate deeper into the body through the airways of respiratory tract. Nanoparticles that penetrate all the way to the end of the airways are retained in the alveoli, and their accumulation can consequently lead to a decrease in lung capacity. One of the things we must not forget is that PM particles are soluble in water, which allows water-soluble substances to be transported in the body after the absorption in lung cells, and some of them can be harmful to human health (for example PAHs, which are considered toxic and carcinogenic). 
The average daily mass concentration of $\mathrm{PM}_{2.5}$ particles only exceeded the daily limit set by WHO in the autumn, so we can conclude that human health is more endangered in colder months of the year. On the other hand, all the measurements exceeded the annual recommended concentration set by $\mathrm{WHO}$, which is at $10 \mu \mathrm{g} / \mathrm{mL}$.

\subsection{Effects of PM particles in erythrocite membranes}

The main goal of our research was to study the influence of PM10 particles on membranes of erythrocytes in human blood. Erythrocytes were exposed to three different concentrations of PM10 particles (50, 100 and $\mu \mathrm{g} / \mathrm{mL}$ ) and later analysed at 3 different intervals (after, $1 \mathrm{~h}, 8 \mathrm{~h}$ and $24 \mathrm{~h}$ ). The aim was to determine which of the concentrations will cause the greatest impact on erythrocyte membranes and consequently on their population in the sample suspension. We found out that PM10 particles form agglomerates in PBS buffer, which later interact with erythrocytes. Using an inverted microscope, we observed that if the agglomerate adheres to the membrane on a large part of its surface, erythrocyte damage can occur. Changes in erythrocyte membranes were observed at all three concentrations. After a few hours of exposure, erythrocytes changed from echinocyte to stomatocyte form. The difference is most noticeable in the sample of erythrocytes which was exposed to particles with a concentration of $200 \mu \mathrm{g} / \mathrm{mL}$, where the change in membrane shape and agglomerate formation is observed after only 1 hour of exposure. The formation of extracellular vesicles, the biomarkers of different diseases, was also observed in the sample of erythrocytes with a particle concentration of $200 \mu \mathrm{g} / \mathrm{mL}$.

We can conclude that the biggest concentration of $\mathrm{PM}_{10}$ particle is the one that has the most pronounced negative effects on erythrocytes. However, the results of flow cytometry show that after a certain time of exposure to PM particles, there is a decrease in erythrocyte population independent on the particle concentration. Moreover, membrane ruptures are also more common when the concentration of particles is the highest. If we compare the effects of PM particles with the effect of black carbon nanoparticles on blood cells, we can conclude that erythrocytes change their shape in both cases after a few hours of exposure. However, when exposed to black carbon nanomaterial, erythrocytes coalesced into bigger agglomerates, whereas no obvious sticking occurred in our case. The reason probably lies in different reaction surfaces of the materials, in particle sizes and chemical nature.

Funding: This research was supported by European Union's Horizon 2020 research and innovation program under grant agreement No 801338 (Ves4Us), and by Slovenian Research Agency through the core foundlings No P3-0388, P1-0034, and projects No L3-2621 and J1-1707.

Institutional Review Board Statement: The study was conducted according to the guidelines of the Declaration of Helsinki, blood was donated voluntarily by the authors of the study.

Conflicts of Interest: The authors declare no conflict of interest.

\section{References}

1. Agencija Republike Slovenije za okolje (2009), Meritve Delcev PM10 na merilnem mestu Hrastnik. Updated 2009. Accessed 26. 02.2020. Avaliable from

https://www.arso.gov.si/zrak/kakovost\%20zraka/poro\%C4\%8Dila\%20in\%20publikacije/PM10_Hrastnik.pdf

2. Agencija Republike Slovenije za okolje (2019), Kakovost zraka v Sloveniji v letu 2018. Updated 2019. Accessed 26.02.2020.

Avaliable from

http://www.arso.gov.si/zrak/kakovost\%20zraka/poro\%C4\%8Dila\%20in\%20publikacije/Letno_Porocilo_2018.pdf

3. American Society of Hematology (2021), Blood Basics. Updated 2021. Accessed 2.1.2021. Avaliable from

https://www.hematology.org/education/patients/blood-basics?

4. Bilban M. Nanodelci. Delo in varnost. 2013; 58(4): 42-54. Available from

https://www.dlib.si/stream/URN:NBN:SI:DOC-71DEG451/ca2a936a-ba21-4d21-8cfd-c39f6921704e/PDF

5. Bilban M. Onesnaževala zraka. Delo in varnost. 2014; 59(4): 16-19. Available from

http://www.dlib.si/stream/URN:NBN:SI:DOC-JZ9QA2GF/b9d39915-55c9-40c1-9f75-3a3ea6c5412f/PDF

6. Blood Transfusion Centre Slovenia (2021), Kri in krvne skupine. Accessed 03.01.2021. Available from

http://www.ztm.si/krvodajalstvo/kri-in-krvne-skupine/ 
7. Carrington D. Air pollution nanoparticles linked to brain cancer for first time. The Guardian. Updated 2019. Accessed 22.02.2021. Avaliable from

https://www.theguardian.com/environment/2019/nov/13/air-pollution-particles-linked-to-brain-cancer-in-new-research

8. Carrington D. Air pollution particles in young brains linked to Alzheimer's damage. The Guardian. Updated 2020. Accessed 22.02.2021. Avaliable from

https:/www.theguardian.com/environment/2020/oct/06/air-pollution-particles-in-young-brains-linked-to-alzheimers-damage

9. European Environment Agency (2019), Air Quality in Europe - 2019 Report. ISSN: 1977-8449. Available from

https://www.eea.europa.eu/publications/air-quality-in-europe-2019

10. Hoffman M. Picture of Blood. WebMD. Published 2014. Dostopno 02.01.2021. Available from https://www.webmd.com/heart/anatomy-picture-of-blood

11. Lesjak T. Ognjemeti in njihov vpliv na prisotnost trdnih delcev v zraku. Bachelor Degree (University of Ljubljana, Faculty of Chemistry and Chemicl Technology, Slovenia). Updated 2016. Accessed 05.02.2021. Available from http://fundacija-avgustakuharja.si/wp-content/uploads/2020/10/2016-diploma-Tadej-Lesjak.pdf

12. Lim HWG, Wortis M, Mukhopadhyay R. Stomatocyte-discocyte-echinocyte sequence of the human red blood cell: Evidence for the bilayer-couple hypothesis from membrane mechanics. PNAS. 2002; 99: 16766-16769. DOI: https://doi.org/10.1073/pnas.202617299

13. Ministry for the Environment (2009), Good Practice Guide for Air Quality Monitoring and Data Management 2009. Updated 2009. Accessed 16. 12. 2020. Available from:

https:/environment.govt.nz/publications/good-practice-guide-for-air-quality-monitoring-and-data-management-2009/

14. Mohandas N, Gallangher PG. Red cell membrane: past, present, and future. Blood. 2008; 112(10): 3939-3948. DOI: 10.1182/blood-2008-07-161166

15. Pečavar Nežmah P. Priprava vodotopne fluorescenčne učinkovine za označevanje normalnih in rakavih celic urotelija sečnega mehurja in vitro (Engl. Synthesis of a water-soluble fluorescent dye for labelling normal and cancerous urothelial cells of the urinary bladder in vitro). Research work. University of Ljubljana, Slovenia. 2018.

16. Pajnič M .Vpliv nanomateriala črnega ogljika na membrane krvnih celic (Engl. Effect of carbon black nanomaterial on blood cell membranes). Doctoral Dissertation (University of Ljubljana, Biotechnical Faculty, Slovenia). Updated 2019. Accesed 18.02.2020. Avaliable from https://repozitorij.uni-lj.si/IzpisGradiva.php?id=112665\&lang=slv\&prip=dkum:8729640:d3

17. Orel M, Berglez K. Onesnaževanje zraka z lebdečimi (PM) delci ter proučevanje njihovega vpliva na membrane celic (Engl. Air pollution with particulate matter (PM) particles and the study of their impact on cell membranes). Research work. University of Ljubljana (Slovenia), and National Institute of Chemistry, Ljubljana (Slovenia). 2018.

18. Siwek K, Osowski S. Data mining methods for prediction of air pollution. Int J Math Comput Sci. 2016; 26(2): 467-478. DOI: 10.1515/amcs-2016-0033

19. World Health Organization (2018). Ambient (outdoor) air pollution. Updated 2018. Accessed 20.02.2021. Avaliable from https://www.who.int/news-room/fact-sheets/detail/ambient-(outdoor)-air-quality-and-health 